\title{
Space-based long-term observation of shrinking grassland habitat: A case-study from central India
}

\author{
N Lele ${ }^{1, *}$, C P Singh ${ }^{1}, \mathrm{R}$ P Singh ${ }^{1}$, J S Chauhan ${ }^{2}$ and J S Parihar ${ }^{1}$ \\ ${ }^{1}$ Environment and Hydrology Division, Space Applications Centre (ISRO), Ahmedabad 380 015, India. \\ ${ }^{2}$ Kanha National Park, Madhya Pradesh Forest Department, Madhya Pradesh, India. \\ ${ }^{*}$ Corresponding author.e-mail: nikhillele@sac.isro.gov.in
}

Grassland ecosystem is critical for survival of herbivores and plays an important role in conservation and management of wildlife. These habitats are widely studied for various issues, including biodiversity, biomass assessment, carrying capacity, etc. Woody species ingression in grasslands is one such important aspect that needs critical attention in protected area as this leads to shrinking of grasslands habitat. This study presents a case of Ronda grassland in Kanha National Park - a well-known protected area in India, known for its herbivore diversity and hard-ground Barasingha (Rucervus duvaceli branderi), in particular. Long-term satellite observation for five decades was carried out to understand spatiotemporal changes. Declassified Corona satellite data, aerial photographs along with satellite datasets in the subsequent period were utilised for this study. The study revealed that 88 ha (16\% of Ronda and surrounding) have been ingressed during 1962-2011, in and around Ronda grassland of Kanha National Park. Rates of ingression on linear transects were found to be $60-120 \mathrm{~m}$ per decade. Field studies and NDVI analysis along the edge of grassland pixels as well as inside region using 1972 as baseline data, indicated woody vegetation replacing area of grassland. It was noted that Butea monosperma is invading more than other species in Ronda grassland, particularly along the stream where moisture availability is higher. Grassland habitats in Kanha are thus shrinking and thus leading to reduction in the area available for herbivore population which has increased in recent years. This can lead to severe impact on carrying capacity of these grasslands.

\section{Introduction}

Grasslands are an important component of protected area system. Many of the rare and endangered wildlife species such as One-horned Rhinoceros (Rhinoceros unicornis), Hard-ground Barasingha (Cervus duvaceli branderi), Nilgiri Thar (Nilgiritragus hylocrius), etc., are totally dependent on the grassland habitat. In India, natural grasslands are spread in the pockets. Among them very few are protected grasslands, such as Banni grassland of Kutch (western India), Eravikulam National Park representing 'shola' (south India), Nandadevi and
Dudhwa National Park (Himalayan and Tarai region), Kaziranga National Park (northeast India), etc.

The current study is focussed on long-term changes in spatial extent of one of the protected grassland in Kanha National Park (Kanha NP). Kanha is one of the richest wildlife diversity areas in India, with Hard-ground Barasingha (Rucervus duvaceli branderi) as one of its flagship species, now having more than 470 individuals (as per 2010 census). Grasslands in Kanha NP serve as best feeding and rousting grounds for Barasingha. Over the period of time, it was found that woody species

Keywords. Kanha National Park; woody ingression; grassland; Corona; aerial photograph; Landsat; IRS-Resourcesat 2. 
in the vicinity have been invading inside the grasslands. This competition of grassland and woody species is ultimately resulting in the conversion of grasslands into woody habitat, thereby reducing the habitat for herbivores depending on grassland species. Therefore, studying and quantifying this woody ingression in grasslands of Kanha NP is of critical importance.

Ingression of woody native species, into grasslands is reported widely across the world (Knoop and Walker 1985; Bush and Van Auken 1986 , 1989; McPherson et al. 1988; Grover and Musick 1990; Àrcher 1994; Wilson 1998; Van Auken 2000; Polley et al. 2002). This phenomenon has various reasons that can be broadly categorized as biotic and abiotic factors. Biotic factors also include anthropogenic pressure that can alter the species composition. Competition between species is considered as one of the key causal factors for woody ingression (Fowler 1986; Casper and Jackson 1997). Bush and Van Auken (1986, 1989) and Wilson (1998) particularly studied below-ground competition for soil nutrients and resources, and reported woody species ingression owing to root characteristics predominantly. Knoop and Walker (1985), followed by Bahre (1995), reported that reduced fire frequency in Arizona grasslands can be correlated with reduced grassland biomass and increased density of woody plants. Off late, invasions are also considered as effect of human-induced climate change and effect of rising $\mathrm{CO}_{2}$ levels that favours growth of particular life-forms while suppressing the others (Van Auken 2000). Herbivory is another important factor of invasion that may suppress growth of particular species by damaging its leaves, stems and even roots; also creating gaps in grassland, allowing woody seeds to germinate and higher levels of herbivory can alter grassland composition into woodland (Archer 1994). Such type of woody ingression leading to the reduction of grassland area is not much reported from Indian region, particularly using remote sensing datasets. Remote sensing based vegetation studies related to succession and competition of species are limited by coarser spatial resolution of historical satellite datasets. Buitenwerf et al. (2012) and Russell and Ward (2014) made use of aerial photographs for studying woody ingression. Lu et al. (2013) monitored change in native vegetation as a result of invasion of $L$. leucocephala (Lam.). In India, studies have mainly focussed on invasive species posing a threat to native ones in key biodiversity hotspots of the country (Murali and Setty 2001; Sastry 2003; Kimothi and Dasari 2010). This study presents a case from Kanha NP, located in central India, where part of grassland is ingressed by native woody species over last five decades, observed using remote sensing data.

\section{Study area}

Kanha NP, part of Deccan peninsula-Central Highlands Biogeographic zone (Rodgers and Panwar 1988), spread across Mandla, Balaghat and Dindori districts of Madhya Pradesh (MP) - covers an area of around $940 \mathrm{~km}^{2}$, spread across $80^{\circ} 20^{\prime}-81^{\circ} 05^{\prime} \mathrm{E}$ and $22^{\circ} 05^{\prime}-22^{\circ} 25^{\prime} \mathrm{N}$. The park area comprises mosaic of meadows and forests in the plain, extensive grasslands on the plateaus, and forests in the rolling hills (Kanoje 2006). According to Champion and Seth (1968), the forest type of Kanha NP mainly consists of moist peninsular sal forest: (forest type $3 \mathrm{C} / \mathrm{C} 2$ ), southern tropical moist deciduous forest: (forest type $3 \mathrm{~A} / \mathrm{C} 2 \mathrm{a}$ ) and southern tropical dry mixed deciduous forest (forest type 5A/C3). The forest is typically represented and dominated by Shorea robusta Roxb., Tectona grandis Linn., Terminalia chebula Retz., Terminalia tomentosa $\mathrm{W} \& \mathrm{~A}$ and Bamboo mixed forests, etc.

Established in 1975, Kanha was one among the first nine protected areas to be brought under the ambit of the Project Tiger launched by the Government of India in 1973. Kanha NP was formulated by evacuating 28 forest villages from the area. The agriculture lands in the village were later transformed into well-known grasslands of Kanha NP and are identified by the name of the village that existed such as Ronda, Silipura, Bamni Dadar, etc. As per the records of forest department, Ronda village was evicted during 1974. Approximately 8\% of the total area of the Kanha NP categorized as grassland. These grassland patches are scattered over 30 locations (Negi and Shukla 2011). Common grass species in the park area are listed in table 1.

Kanha NP is one of the very well studied areas in terms of its floral and faunal diversity. After the preparation of flora and fauna of this region published by Forsyth (1889), Brander (1923) and Schaller (1967) pioneered the ecological study of large mammals in Kanha NP. This was followed by a wide number of studies on habitat quality, wildlife ecology and wildlife corridor planning (Martin 1976; Panwar 1977; Ranjitsinh 1982, 1989; Parihar et al. 1986a; Gopal 1995; Jhala et al. 2008; Sharma et al. 2010). Parihar et al. (1986b), Roy et al. (1986) and Porwal and Roy (1991) evaluated the habitats of Kanha National Park through remote sensing techniques for biodiversity characterization, spectral characteristics and biophysical attributes. However, the phenomenon of ingression of the woody native species in grasslands of Kanha NP is not studied from the perspective of knowing the actual area ingressed since its inception. Therefore, the current study is taken up in Ronda grasslands and surroundings in Kanha NP (figure 1), for analysing woody ingression in a grassdominated landscape. The study area constituting 
Table 1. List of dominant grass species in Kanha National Park (in alphabetical order).

\begin{tabular}{lll}
\hline Apluda mutica & Eulalia trispicata & Psuedopogonatherum contortum \\
Arthraxon quartinianus & Heteropogon contortus & Saccharum spontaneum \\
Bothriochloa odorata & Ischaemum indicum & Schizachyrium brevifolium \\
Chionachne koenigii & Ischaemum rugosum & Setaria glauca \\
Diandrochloa japonica & Iseilema prostratum & Sorghum halepense \\
Digitaria stricta & Mnesithea laevis & Themeda quadrivalvis \\
Dimeria connivens & Narenga porphyrocoma & Themeda triandra \\
Eragrostiella bifaria & Panicum austroasiaticum & Vetiveria zizanioides \\
Eragrostis unioloides & Phargmites karka & \\
\hline
\end{tabular}

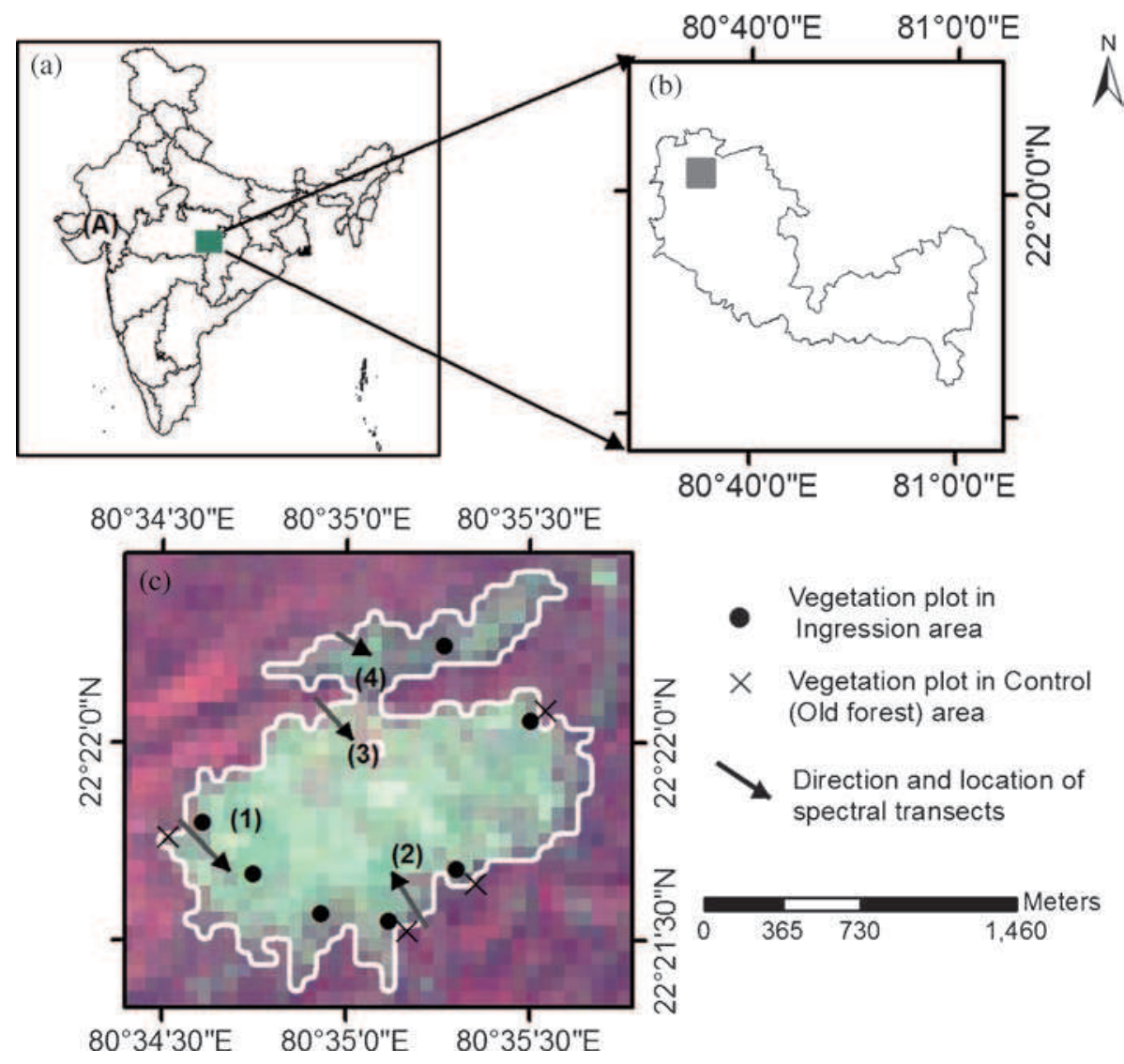

Figure 1. (a) Location of Kanha NP in Madhya Pradesh (India); (b) Ronda grassland shown as small box inside Kanha NP; and (c) Ronda grassland showing location of vegetation plots, overlaid on 1972 Landsat MSS data, indicating the grassland and tree boundary. Numbers (1-4), along with arrows indicate location and direction of spectral transects.

Ronda grassland and surroundings (figure 1c) has 123 ha of grassland out of total area of 540 ha. This grassland is surrounded by woody vegetation on all the sides.

\section{Datasets}

Long-term multi-temporal satellite datasets are helpful for understanding spatio-temporal changes in natural vegetation. Corona satellite data of 1962 has been used in the present study in order to cover the pre-Landsat period. Aerial photographs of Kanha NP during 1979 were also used to delineate vegetation boundary. Landsat-1 MSS (year 1972), Landsat-4 TM (year 1990), Landsat-7 ETM (year 2001) and IRS Resourcesat-2 LISS 3 (year 2011) data were used. Near-decadal interval temporal data was thus utilised for studying vegetation changes at Ronda. Details of the data used are listed in table 2. Species level ground-based data were collected during field visits.

\section{Methodology}

Panchromatic datasets (Corona data and aerial photographs) were co-registered and used for 
Table 2. Satellite data used in the study.

\begin{tabular}{|c|c|c|c|c|}
\hline $\begin{array}{l}\text { Sl. } \\
\text { no. }\end{array}$ & Platform/sensor & Date & $\begin{array}{c}\text { Spatial } \\
\text { resolution }(\mathrm{m})\end{array}$ & Source \\
\hline 1 & Corona satellite data & May 7, 1962 & $32^{*}$ & www.earthexplorer.org \\
\hline 2 & Landsat-1 MSS & December 17, 1972 & 58 & www.glcf.org \\
\hline 3 & Aerial photographs & April 1979 & $6^{*}$ & Madhya Pradesh Forest Department \\
\hline 4 & Landsat-4 TM & November 17, 1990 & 30 & www.glcf.org \\
\hline 5 & Landsat-7 ETM & November 2, 2001 & 30 & www.glcf.org \\
\hline 6 & $\begin{array}{l}\text { IRS Resourcesat-2 } \\
\text { LISS } 3\end{array}$ & December 8, 2011 & 24 & $\begin{array}{l}\text { National Remote Sensing Centre } \\
\text { (NRSC), India }\end{array}$ \\
\hline
\end{tabular}

Note. *: as computed after registration and resampling.

on-screen grassland boundary demarcation. Multispectral datasets were corrected for atmospheric effects and were normalised using Dark Object Subtraction (DOS) method (Chavez 1996).

Normalised Difference Vegetation Index (NDVI) for all multispectral datasets was computed. Multisensor NDVI normalisation technique given by Steven et al. (2003) was adapted by using Landsat7 ETM (2001) as reference data, for NDVI normalisation as well as rectification with other datasets. Re-calculated NDVI data were subjected to threshold technique based on known field locations for trees and grasslands (NDVI threshold of 0.36 such that, NDVI $>0.36$, were considered as trees) to create binary data of tree and grassland. All the images were brought to uniform pixel size of $30 \mathrm{~m}$ pixel resolution for spatial similarity using nearest neighbourhood resampling method. Postclassification change detection for medium resolution is chosen because of the ability to compare products from different satellites and the intrinsic simplicity of the results (Mas 1999; Lu et al. 2004). The grassland and tree area classes were compared taking 1972 as the base year.

Field studies involved laying down vegetation plots of $20 \times 20 \mathrm{~m}$ size, based on species area curve method (IIRS 2002). Plots were laid in ingression areas and native forests (control sites, showing no signs of ingression) and all the trees were measured for GBH (Girth at Breast Height). Simpson's diversity index (Simpson 1949; equation 1) and Importance Value Index (IVI) (equation 2) were computed to understand diversity and dominance in both the types of vegetation plots.

$$
\text { Simpson's diversity }=\sum\left(\frac{n}{N}\right)^{2},
$$

where $n=$ total number of organisms of a particular species; $N=$ Total number of organisms of all species.

$$
\begin{aligned}
\text { IVI }= & (\text { relative frequency })+(\text { relative density }) \\
& +(\text { relative dominance })
\end{aligned}
$$

Relative frequency

$$
=\left(\frac{\text { Frequency of one species }}{\text { Sum of frequency of all species }}\right) \times 100
$$

Relative density

$$
=\left(\frac{\text { Density of one species }}{\text { Sum of density of all species }}\right) \times 100
$$

Relative dominance

$$
\begin{aligned}
& =\left(\frac{\text { Basal cover of a species }}{\text { Sum of total stand basal cover of all species }}\right) \\
& \quad \times 100
\end{aligned}
$$

In order to study the pattern of ingression in the temporal domain, spectral transects of 400-600 m were drawn on the NDVI composite image (figure 1). Further, the rates of ingression were estimated on decadal basis along the line of transects. Colditz et al. (2012) suggested differences of up to $5 \%$ in the change matrix for a misregistration of $100 \mathrm{~m}$ while using multi-resolution data. In the present study, error of misregistration of $45 \mathrm{~m}$ (involving registration of coarser resolution data to finer resolution data) was noted. This accounted for $2.25 \%$ of the change in the area of ingression, which is approximately \pm 2 ha. Further, for validating the process of densification on the edge of grasslands, the change in NDVI values across the edge pixels of the grassland (using baseline data of 1972) were analysed.

\section{Results and discussion}

\subsection{Spatio-temporal land use dynamics}

On the basis of multi-temporal data of Ronda and surrounding, it was found that $88 \pm 2$ ha has been ingressed during 1962 and 2011. The area of grassland was found to be gradually shrinking from 223 ha in 1962 to 135 ha in 2011, with gradual reduction in the grassland area (figure 2 and table 3 ). Although the Ronda village was evicted in 1974, the nominal change of $6 \pm 2$ ha from 1962 to 1972 
has been observed but this is not significant as compared to changes in subsequent periods.

In order to understand the dynamics of ingression process, four spectral transects were analysed in various directions on NDVI multi-temporal datasets (figure 1). Length of transect varied as per site, depending on the extent of ingression. All the transects were taken up to $600 \pm 30 \mathrm{~m}$, except for

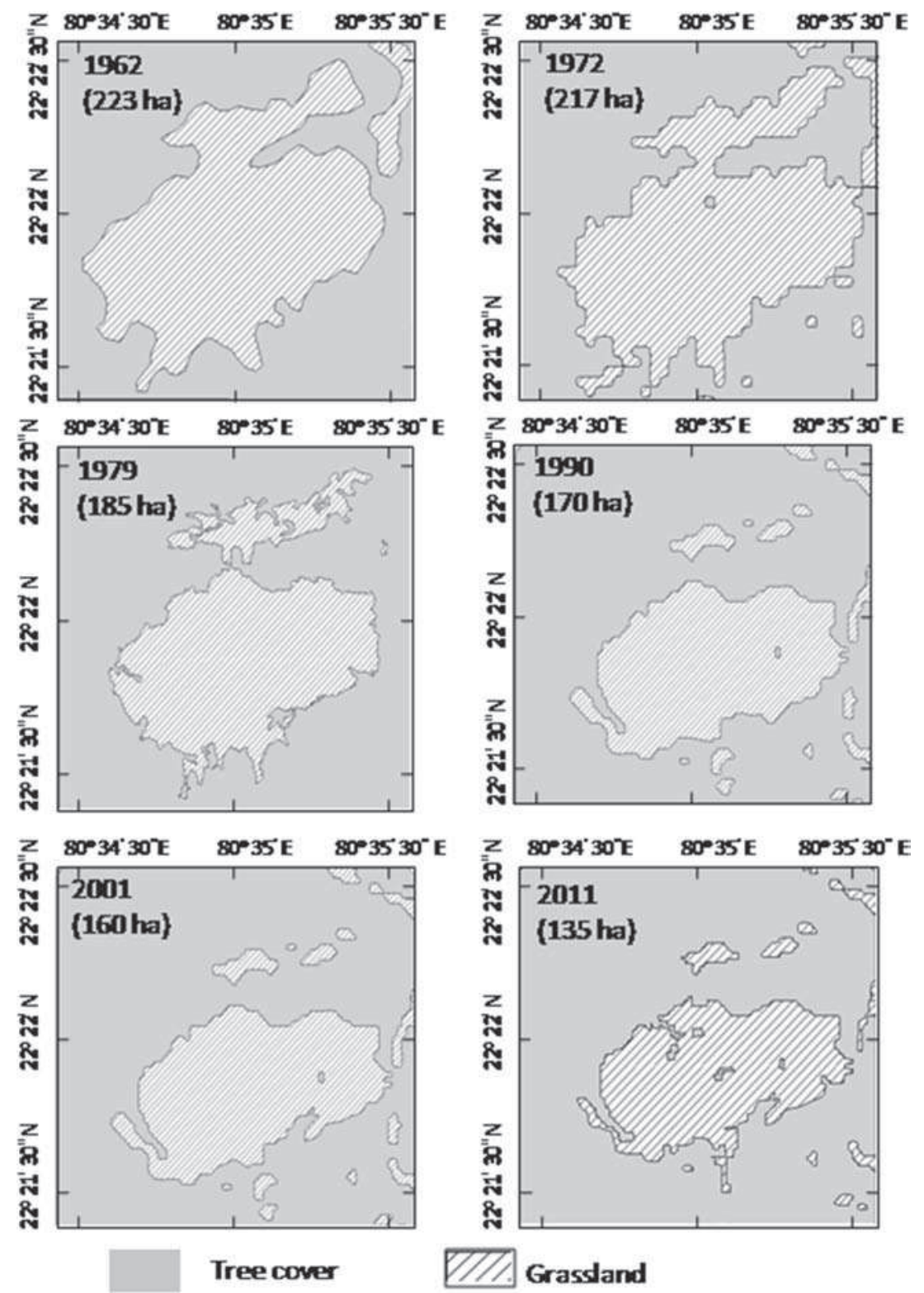

Figure 2. Grassland and tree extent in Ronda as seen on temporal datasets as listed further: (a) 1962 (data source: Corona); (b) 1972 (data source: Landsat MSS); 1979 (data source: Aerial photograph); 1990 (data source: Landsat-4 TM); 2001 (data source: Landsat-7 ETM); 2011 (data source: IRS Resourcesat LISS 3). Number in parenthesis of each panel indicates grassland area in hectares.

Table 3. Area under grassland and NDVI along the edge at Ronda grassland.

\begin{tabular}{ccc}
\hline Year & $\begin{array}{c}\text { Grassland area } \\
\text { (in hectares })\end{array}$ & Average edge pixel NDVI \\
\hline 1962 & 223 & Not applicable for Corona data \\
1972 & 217 & 0.23 \\
1979 & 185 & Not applicable for aerial photograph \\
1990 & 170 & 0.30 \\
2001 & 160 & 0.39 \\
2001 & 135 & 0.40 \\
\hline
\end{tabular}


transect 4, where it was $450 \mathrm{~m}$, owing to smaller size of ingression patch. Pattern of ingression based on NDVI differencing using 1972 as base line data,
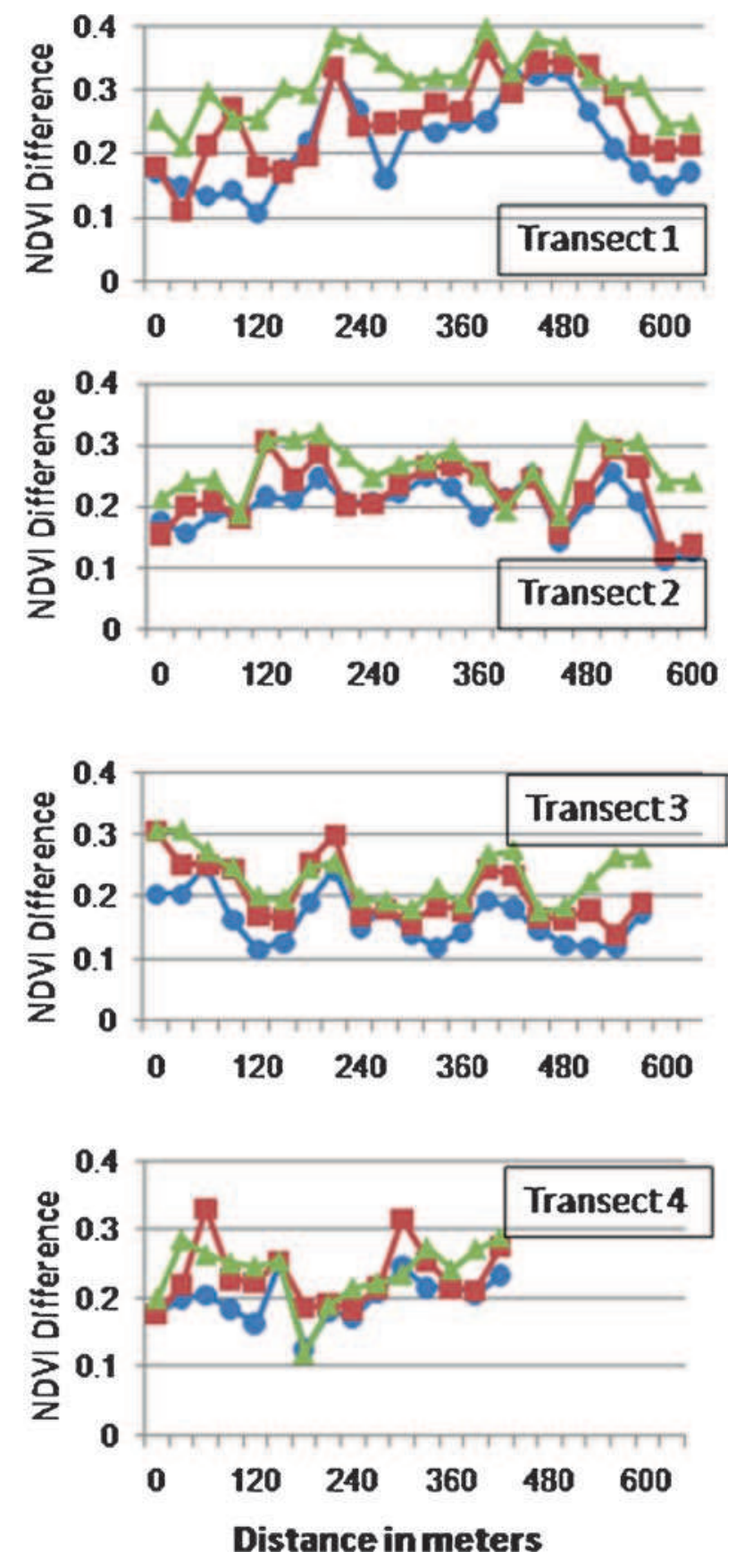

Figure 3. NDVI transects at four different locations over ingression area showing temporal variability during each time interval. $\mathrm{X}$-axis indicates distance in meters; $\mathrm{Y}$-axis is NDVI difference using 1972 as base data. was studied by differencing base year from respective year (viz., 1990-1972, 2001-1972 and 20111972). Pattern of ingression based on NDVI difference is shown in figure 3, indicating how NDVI changed at every pixel on the transect.

Using 1972 as base data for NDVI differentiation, the incremental pattern of ingression can be seen. This is also indicated by comparing average NDVI difference values from each transect (table 4), which suggests that rate of ingression increased with time.

In order to understand the densification process across the ecotonal region, where grassland and woody species co-exist, the edge pixels of the grassland were analysed in temporal domain, keeping 1972 boundary line as reference. Average NDVI value was observed to vary from 0.23 to 0.40 from 1972 to 2011 (table 3), suggesting that there is an increasing trend of NDVI values (figure 4). Increase in NDVI values is attributed to increase in density of existing tree species located along the edge of grassland.

\subsection{Species dynamics}

It was noted that most of the trees in the ingression area were relatively of younger age (5-15 years), while surrounding areas have trees of old age (40 years and more), as observed from the girth and height. In all, 109 individuals belonging to 15 species from control plots and 106 individuals

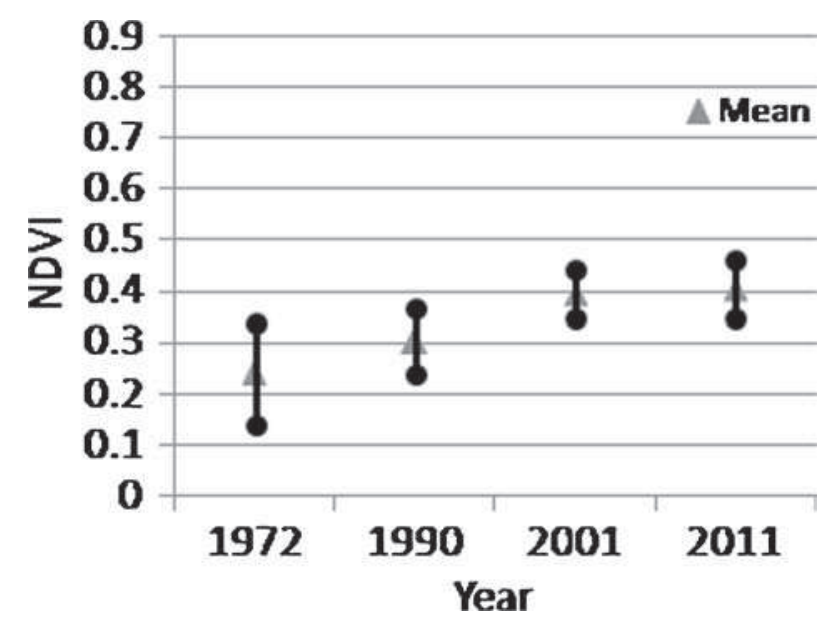

Figure 4. NDVI values (mean \pm standard deviation) on the edge of grassland pixels (1972 edges as reference line).

Table 4. Average values of NDVI difference across all transects.

\begin{tabular}{lcccc}
\hline $\begin{array}{l}\text { Difference } \\
\text { interval (year) }\end{array}$ & Transect 1 & Transect 2 & Transect 3 & Transect 4 \\
\hline $1990-1972$ & 0.21 & 0.19 & 0.16 & 0.20 \\
$2001-1990$ & 0.25 & 0.22 & 0.20 & 0.23 \\
$2011-2001$ & 0.29 & 0.26 & 0.25 & 0.25 \\
\hline
\end{tabular}


belonging to 18 species from ingression plots were reported. Species common to both the types of plots or having relative dominance values $>1$ were considered for comparative analysis of IVI.

This accounted for 11 common species and Butea monosperma (Palash) showed very high value of relative dominance (24.9) in ingression plots. Association of Shorea robusta, Terminalia tomentosa, Syzygium cumini, Lagerstroemia parviflora, and Diospyros melanoxylon are commonly found native species in moist deciduous forest. It was interesting to note that Butea monosperma was not found in the control plots, though it is known to grow in open areas of dry deciduous forests of central and western India (Champion and Seth 1968) and also in the surroundings of Ronda. Species' Importance Value Index (IVI) in ingression and control plots is shown in table 5 and figure 5 . It can be noted that Shorea robusta and Diospyros melanoxylon are among dominant species in this region, showed lesser values in ingression plots, indicating that they are possibly replaced by other species. Syzygium cumini and Terminalia tomentosa also indicated marginal reduction in IVI values. It was interesting to note that along the sides of stream flowing down from adjoining hills, Butea monosperma was found to dominate the vegetation to an extent that there were no other tree species observed. These streams generally get dried up at the end of the winter season (January/February). Transects 1 and 2 are located along the stream and are dominated by Butea monosperma. Surrounding the edge of grassland, Lagerstroemia parviflora, Terminalia tomentosa, Shorea robusta and Diospyros melanoxylon have shown significant increase in density. This was evident in the field visit as the vegetation has young and old-age trees. Transects 3 and 4 represent this area surrounding the main grassland. Increase in the density of native species is attributed to protection measures in the national park. Simpson's diversity values for control and ingression plots were found to be 0.19 and 0.13 respectively, indicating higher diversity in ingression plots.

\subsection{Rate of ingression}

Directional change in woody ingression was observed on the basis of temporal data. It was noted that the open grassland boundary shrunk as a result of woody ingression. Maximum rate of change in five decades was studied for directional changes along the 4 transects. As mentioned earlier, transects 1 and 2 were along the side of streams that generally accumulate water till the end of winter season, and it is assumed that these areas would be better in terms of soil moisture availability, though no clear experiment/data collection for soil moisture was done in the present study. In these areas, rate of change was found to be $120 \mathrm{~m}$ per

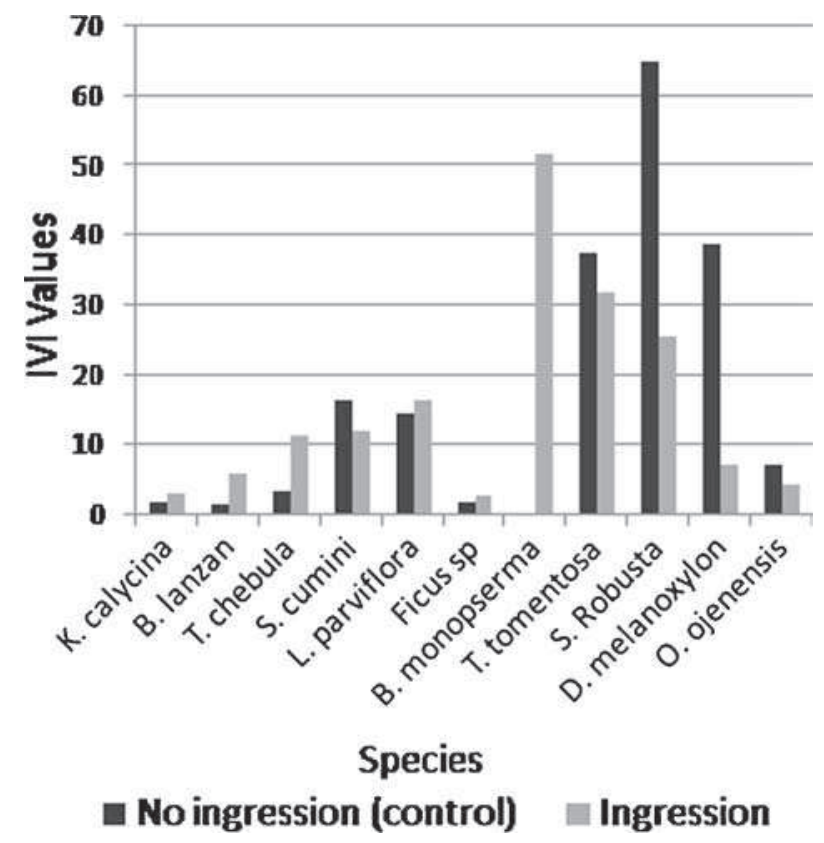

Figure 5. IVI values in ingression and control plots.

Table 5. List of species observed and Importance Value Index (IVI) values.

\begin{tabular}{llrr}
\hline Botanical name & $\begin{array}{c}\text { Vernacular } \\
\text { name }\end{array}$ & $\begin{array}{c}\text { IVI } \\
\text { (control) }\end{array}$ & $\begin{array}{c}\text { IVI } \\
\text { (ingression) }\end{array}$ \\
\hline Kydia calycina Roxb. & Baranga & 1.8 & 3.2 \\
Buchanania lanzan Spreng. & Chiranji & 1.4 & 6.0 \\
Terminalia chebula Retz. & Harra & 3.5 & 11.2 \\
Syzygium cumini (L.) Skeels. & Jamun & 16.3 & 11.8 \\
Lagerstroemia parviflora (L.) & Lendia & 14.5 & 16.3 \\
Ficus sp. & Murja & 1.9 & 2.8 \\
Butea monosperma (Lam.) Taub. & Palash & 0.0 & 51.8 \\
Terminalia tomentosa W \& A. & Saja & 37.5 & 31.8 \\
Shorea robusta Roxb. & Sal & 65.0 & 25.4 \\
Diospyros melanoxylon Roxb. & Tendu & 38.7 & 7.3 \\
Ougeinia oojeinensis & Tinsa & 7.2 & 4.5 \\
\hline
\end{tabular}


decade. On the remaining transect, it was found to be $60 \mathrm{~m}$ per decade. In presence of availability of moisture or any favourable resources, species growth may be faster and thus explains faster rate in case of stream-side vegetation.

One more such grassland site within Kanha NP - Silipura was taken up for supporting the results of tree ingression, though the complete suite of datasets are underway. Since the aerial photographs mosaic for Silipura region is under preparation, we considered the satellite derived five-time

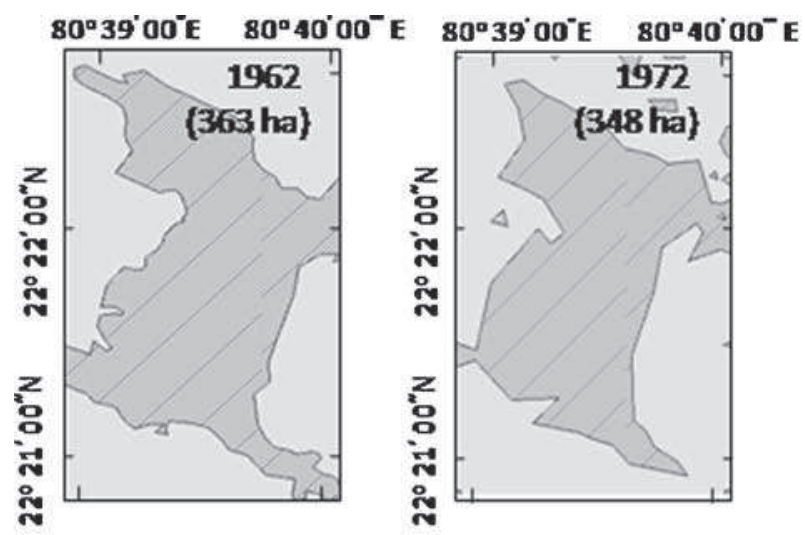

$80^{\circ} 39^{\circ} 00^{\circ} \mathrm{E} \quad 80^{\circ} 40^{\circ} 00^{-}$E $80^{\circ} 39^{\circ} 00^{\circ} \mathrm{E} \quad 80^{\circ} 40^{\circ} 00^{\circ} \mathrm{E}$
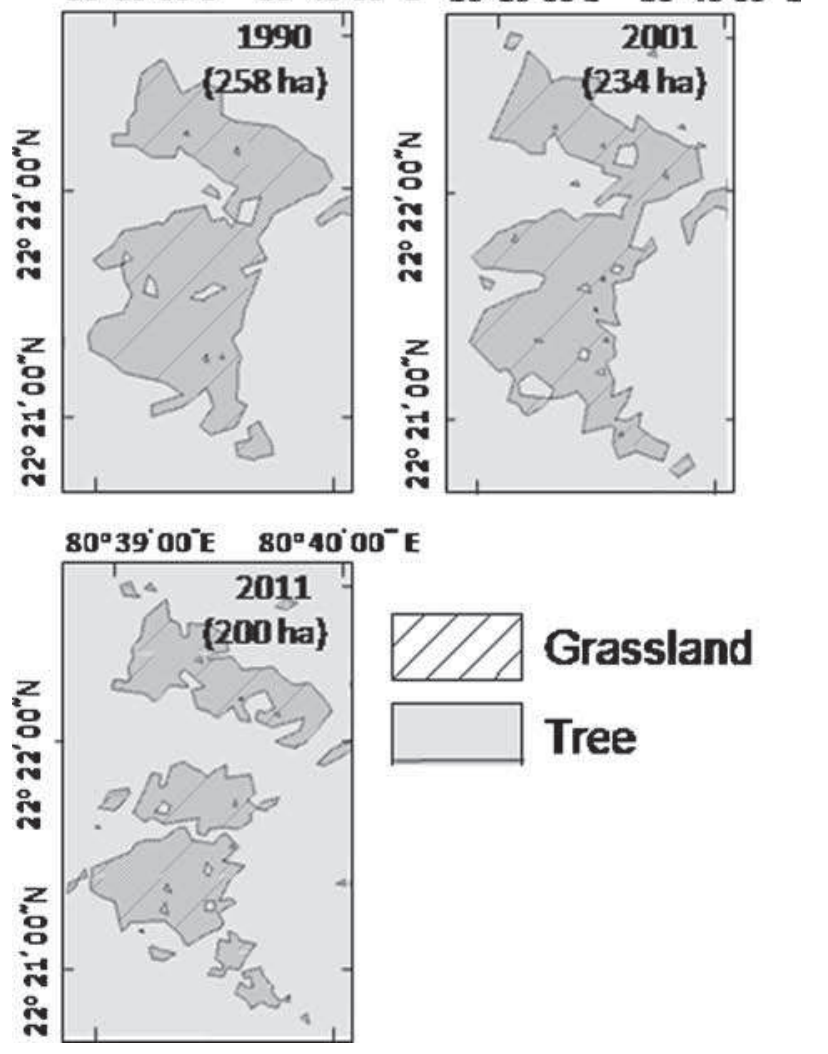

Figure 6. Grassland and tree extent in Silipura grassland as seen on temporal datasets as listed further: (a) 1962 (data source: Corona); (b) 1972 (data source: Landsat - MSS); (c) 1990 (data source: Landsat-4 TM); (d) 2001 (data source: Landsat-7 ETM); (e) 2011 (data source IRS Resourcesat 2-LISS 3). datasets for this site. Procedurally, the same steps were followed for Silipura and surroundings. Tree and grassland boundary was derived from 1962, 1972, 1990, 2001 and 2011 datasets. Out of 860 ha totalling Silipura grassland and surroundings, 163 ha has been found to be ingressed during 19622011. Gradual shrinking of Silipura and surroundings is shown in figure 6, where grassland area was reduced from 363 ha (in 1962) to 200 ha (in 2011).

\section{Conclusion}

Present study clearly brings out that substantial changes have happened in grasslands due to woody native species ingression. About $16 \%$ area of Ronda region and $18 \%$ of Silipura region have been ingressed in five decades. NDVI differencing and edge pixels analysis indicated the change from grassland to woody species and further densification of the same. It was observed that Butea monosperma was found ingressing more than any other species with luxuriant growth along the streams. Rates of ingression were found to be 60-120 m per decade.

Globally, this phenomenon is known to occur and issues related to woody ingression in grasslands are documented and studied in terms of physiological processes, soil characteristics, increasing levels of $\mathrm{CO}_{2}$ and so on. In India, there are not too many records of such changes, particularly using long-term satellite observations. Kanha National Park and its grasslands are known for herbivore diversity. In the recent years, herbivore populations in Kanha, particularly Barasingha (Cervus duvaceli branderi), Chital (Axis axis) and Sambar (Cervus unicolor) have increased significantly. Shrinking of grasslands will not only lower the carrying capacity but also degrade the quality of grasslands due to heavy grazing of preferred grass species. Unless a specified area for grassland is not maintained, it may severely affect the herbivore populations, including the flagship species of hard-ground Barasingha. For this reason, it will be important to notify certain area for grasslands and protect them from possible ingression. It is also necessary to undertake similar studies at prominent grassland sites in the country in order to protect the grassland ecosystem.

\section{Acknowledgements}

This work was carried out as part of project entitled 'Energy \& Mass Exchange in Vegetative Systems' under ISRO-Geosphere Biosphere Programme (ISRO-GBP-EMEVS). Authors are thankful to Director, Space Applications Centre 
(ISRO), Ahmedabad for necessary support in conducting this study. Authors acknowledge support of Madhya Pradesh forest department staff at Kanha National Park for necessary help during field work and data collection.

\section{References}

Archer S 1994 Woody plant encroachment into southwestern grasslands and savannas: Rates, patterns and proximate causes; In: Ecological implications of livestock herbivory in the west (eds) Vavra M, Laycock W A and Pieper R D (Denver: Soc. Range Management), pp. 13-69.

Bahre C J 1995 Human impacts on the grasslands of southeastern Arizona; In: The desert grassland (eds) McClaran M P and Van Devender T R (Tucson: Univ. Arizona Press).

Brander A D 1923 Wild animals in central India (London: Edward Arnold \& Co), Indian reprint (1982) Natraj Publishers, Dehra Dun.

Buitenwerf R, Bond W J, Stevens N and Trollope W S W 2012 Increased tree densities in South African savannas: $>50$ years of data suggests $\mathrm{CO}_{2}$ as a driver; Global Change Biology 18(2) 675-684.

Bush J K and Van Auken O W 1986 Changes in nitrogen, carbon, and other surface soil properties during secondary succession; Soil Sci. Soc. Am. J. 50 1597-1601.

Bush J K and Van Auken O W 1989 Soil resource levels and competition between a woody and herbaceous species; Bull. Torr. Bot. Club $11622-30$.

Casper B B and Jackson R B 1997 Plant competition underground; Ann. Rev. Ecol. Syst. 28 545-570.

Champion H G and Seth S K 1968 A revised survey of forest types of India; New Delhi Govt. Publication, New Delhi.

Chavez P S 1996 Image-based atmospheric corrections Revisited and improved; Photogramm. Engg. Remote Sens. 62 1025-1036.

Colditz R R, Acosta-Velazquez J, Gallegos J, Lule A, Rodríguez-zúñiga M, Maeda P, Lopez M and Ressl R 2012 Potential effects in multi-resolution post-classification change detection; Int. J. Remote Sens. 33(20) 64266445.

Forsyth J 1889 The Highlands of Central India (London: Chapman and Hall), Indian reprint (1975) Natraj Publishers, Dehra Dun.

Fowler N L 1986 The role of competition in plant communities in arid and semiarid regions; Ann. Rev. Ecol. Syst. $1789-110$.

Gopal R 1995 The biology and ecology of Hard Ground Barasinhga (Cervus duvaceli branderi) in Kanha National Park;. Dr Harisingh Gaur Vishwavidyalaya, Sagar (M. P.), Ph. D. Thesis.

Grover H D and Musick H B 1990 Shrubland encroachment in southern New Mexico, USA: An analysis of desertification processes in the American southwest; Climate Change 17 305-330.

IIRS (Indian Institute of Remote Sensing) 2002 Biodiversity characterisation at landscape level in Western Ghats India, using satellite remote sensing and geographic information system; Published by Indian Institute of Remote Sensing (National Remote Sensing Agency), Department of Space, Government of India, Dehradun, India (ISBN: 81-901418-1-3), 32p.

Jhala Y V, Gopal R and Qureshi Q (eds) 2008 Status of tigers, co-predators and prey in India; National Tiger Conservation Authority \& Wildlife Institute of India, Dehradun, TR08/001.
Kanoje R S 2006 Ecological impact of conservation measures on swamp deer and its habitat in Kanha National Park: A case study; In: Conservation Biology in Asia (eds) McNeely J A, McCarthy T M, Smith A, OlsvigWhittaker L and Wikramanayake E D, Society for Conservation Biology Asia Section and Resources Himalaya, Kathmandu, Nepal, pp. 261-276 (ISBN 99946-996-9-5).

Kimothi M M and Dasari A 2010 Methodology to map the spread of an invasive plant (Lantana camara L.) in forest ecosystems using Indian remote sensing satellite data; Int. J. Remote Sens. 31(12) 3273-3289.

Knoop W T and Walker B H 1985 Interactions of woody and herbaceous vegetation in a southern African savanna; J. Ecol. 73 235-253.

Lu D, Mausel P, Brondizio E and Moran E 2004 Change detection techniques; Int. J. Remote Sens. 25 23652407.

Lu M L, Huang J Y, Chung Y L and Huang C Y 2013 Modelling the invasion of a central American Mimosoid tree species (Leucaena leucocephala) in a tropical coastal region of Taiwan; Remote Sens. Lett. 4(5) 485-493.

Martin C 1976 Status and ecology of Barasingha (Cervus duvauceli branderi); Ph.D. Thesis, Zurich University, Switzerland.

Mas J F 1999 Monitoring land-cover changes: A comparison of change detection techniques; Int. J. Remote Sens. 20 139-152.

McPherson G R, Wright H W and Wester D B 1988 Patterns of shrub invasion in semi-arid Texas grasslands; $\mathrm{Am}$. Midl. Nat. 120 391-397.

Murali K S and Setty R S 2001 Effect of weeds Lantana camara and Chromelena odorata growth on the species diversity, regeneration and stem density of tree and shrub layer in BRT sanctuary; Curr. Sci. 80 675-678.

Negi H S and Shukla R 2011 Tiger conservation plan for the Kanha Tiger Reserve: Sub-plan - Core Zone (for the period 2011-2012 to 2021-2022).

Panwar H S 1977 Success with the Branderi Barasingha (Cervus duvauceli branderi) in Kanha National Park; The Working Meeting of the IUCN-SCC, Deer Specialist Group, held at Longview, Washington, USA.

Parihar J S, Chaturvedi N, Panigrahi S and Kotwal P C 1986a Study of network of wildlife reserves in eastern Madhya Pradesh using remote sensing data; In: Results from the Joint Indo-Soviet Remote Sensing Experiment TERRA on Board Salyut-7, ISRO Spec. Publ., ISROSP17-86, pp. 83-94.

Parihar J S, Kotwal P C, Panigrahi S and Chaturvedi N 1986b Study of wildlife habitat using high resolution space photographs - A case study of Kanha National Park; In: Results from the joint Indo-Soviet remote sensing experiment TERRA on-board Salyut-7, ISRO Spec. Publ., ISROSP-17-86, pp. 65-82.

Polley H W, Johnson H B and Tischler C R 2002 Woody invasion of grasslands: Evidence that $\mathrm{CO}_{2}$ enrichment indirectly promotes establishment of Prosopis glandulosa; Plant Ecol. 164 85-94.

Porwal M C and Roy P S 1991 Understory characterisation using aerial photographs; Environ. Conser. 18(1) 4550 .

Ranjitsinh M K 1982 Ecology and behaviour of the Indian blackbuck (Antelope cervicapra Linn.), Ph.D. Thesis, The Saurastra University, India.

Ranjitsinh M K 1989 The Indian Blackbuck; Natraj Publishers, Dehra Dun.

Rodgers W A and Panwar H S 1988 Planning a wildlife protected area network in India; A report submitted to Ministry of Environment, Forests and Wildlife, Government of India. Vols. 1 and 2. 
Roy P S, Saxena K G, Pant D N and Kotwal P C 1986 Analysis of vegetation types using remote sensing techniques for wildlife habitat evaluation in Kanha National Park; Seminar cum Workshop on Wildlife Habitat Evaluation Using Remote Sensing Techniques, IIRS \& WII, Dehra Dun.

Russell J M and Ward W 2014 Remote sensing provides a progressive record of vegetation change in northern KwaZulu-Natal, South Africa, from 1944 to 2005; Int. J. Remote Sens. 35(3) 904-926.

Sastry K L N 2003 Biodiversity threat through exotic species monitoring and management using remotely sensed data and GIS techniques - A case study of Banni (Kachchh) Gujarat, India; Map India Conference 2003, India.

Schaller G B 1967 The deer and tiger: A study of wildlife in India; University of Chicago Press.
Sharma R K, Jhala Y, Qureshi Q, Vattakaven J, Gopal R and Nayak K 2010 Evaluating capture-recapture population and density estimation of tigers in a population with known parameters; Animal Conservation 13 94-103.

Simpson E H 1949 Measurement of diversity; Nature 163 688.

Steven M D, Malthus T J, Baret F, Hui X and Chopping M J 2003 Intercalibration of vegetation indices from different sensor systems; Remote Sens. Environ. 88 412-422.

Van Auken O W 2000 Shrub invasions of North American semiarid grasslands; Ann. Rev. Ecol. Evolution and Systematics 31 197-215.

Wilson S D 1998 Competition between grasses and woody plants; In: Population Biology of Grasses (ed.) Cheplick G P (Cambridge, UK: Cambridge Univ. Press), pp. 231-54. 